\section{俩 Heighten Science \\ P U B L I C I T I O N S Corporation ISSN 2575-0194}

*Address for Correspondence: Jamal Safi, Al-Azhar University, Gaza and Environmental Protection and Research Institute, Gaza, Palestine, Email: eprigaza@palnet.com

Submitted: 02 January 2019 Approved: 11 January 2019

Published: 14 January 2019

Copyright: (@) 2019 Ashour A, et al. This is an open access article distributed under the Creative Commons Attribution License, which permits unrestricted use, distribution, and reproduction in any medium, provided the original work is properly cited

Check for updates

\title{
Environmental Risk factors associated with Breast Cancer in Gaza Strip
}

\author{
Asad Ashour ${ }^{1}$ and Jamal Safi ${ }^{2 *}$ \\ 'Education Officer, Norwegian Refugee Council, Gaza Strip, Palestine \\ ${ }^{2}$ Al-Azhar University-Gaza and Environmental Protection and Research Institute, Gaza, Palestine
}

\section{Abstract}

The study aimed to identify possible environmental risk factors for breast cancer among women in Gaza Strip and conducted in 2010. A case- control study design was used with face to face interviews by structured questionnaire with breast cancer patient women as well as healthy women. Statistical Package of Social Science (SPSS) was used to analyze the collected data. The study population was 288 women, 144 were women with breast cancer (cases) and 144 were healthy women (controls) with response rate $100 \%$ for cases as well as controls. The study was carried out in the two main hospitals in Gaza Strip (El-Shifa and European Gaza) and on cases who had a regular follow up in each hospital, while controls have been chosen from women who had no history of breast cancer by mammogram or by self-examination. In this study the main statistically significant risk factors were; marital status, educational status, physical trauma on breast, medication for infertility treatment, eating red meat $500 \mathrm{~g}$ or more weekly, eating canned food, eating chicken skin, eating raw and cooked vegetables, using oils with saturated fats in cooking, living in or beside a farm, dealing with crops with naked hands, working in a farm during pesticides application or during 24 hours of pesticides application, cleaning pesticides' equipment, living with people working in a farm or a agricultural field, and application of pesticides personally. In contrary, no statistically significant differences were found between cases and controls in relation to area of residency, exposure to $\mathrm{X}$-ray in the past, having radiation therapy, getting contraceptive pills, using hair dyes, using anti-deodorant underarm, using facial cosmetics, using hair removal ointment, washing vegetables and fruits, buying and transporting pesticides, and wearing protective tools during pesticides mixing and application.

\section{Introduction}

Worldwide, breast cancer is the most frequent cancer among women with an estimated 1.38 million new cases diagnosed in 2008 (23\% of all cancer), and still as the most frequent cause of death in women in both developing (269000 deaths) and developed regions (189000 deaths) [1]. In Eastern Mediterranean region, breast cancer affects women in younger age and is detected at a late stages [2]. Nowadays, breast cancer ranks as number one between all cancer types in all countries of Arab World [3].

In Palestinian territories, the total reported new cases of cancer were 1,623 $(72 \%$ in West Bank, 28\% in Gaza Strip) with incidence rates of 43.1/100 000 population, breast cancer occupies the first type of cancer $(17.3 \%$ of total cancer morbidity, $31.4 \%$ of female cancer, $21.1 \%$ of female morbidity) [4]. Breast cancer in Gaza Strip was the common cancer among women since 1990-1999, and ranked as number one of all cancer types in women with incidence rate of $19.3 / 100000$ population $(32.3 \%$ among female cancer, $16.7 \%$ of cancer morbidity among the total population) [5,6]). Nowadays in Gaza strip there are 120 new breast cancer cases annually [7].

Several factors, both endogenous and exogenous are known to affect the risk of breast cancer such as lifestyle, hormonal status, anthropometric characteristics, 
radiation and genetic predisposition [8-10]. Gary in 2010 [11], has linked the increasing in incidence of breast cancer to synthetic chemicals noting that such increasing had paralleled the proliferation of synthetic chemicals since World War II. It has been estimated that more than $80 \%$ of breast cancer are associated with environmental factors that include the exposure to contaminants, lifestyle, and diet [12].

There is considerable international concern where 70,000 synthetic chemicals in our environment may be directly linked to a large percentage of breast cancer cases, but there are no epidemiological studies to determine this $[13,14]$. Accordingly, Gaza Strip as one of the most densely populated areas worldwide has already started to experience deterioration of environmental quality where drinking water shortage, high salinity water, lack of solid waste treatment, marine pollution, poverty and some restricted, cancelled or banned pesticides still enter in Gaza Strip and widely used [6,15-17]. However, there are no previous studies in our country aimed to identify the common environmental risk factors associated with breast cancer among women. So that, this study presents the first research on such common environmental risk factors that may affect the risk of breast cancer among women which covers 5 Governorates in Gaza Strip.

\section{Materials and Methods}

A case-control study was conducted from May 2010 to January 2011 in two main hospitals (El-Shifa and European Gaza) which cover the 5 Governorates of Gaza Strip. The eligible cases were all incident breast cancer women patients living in Gaza Strip and who had a regular follow up in the two main hospitals during the study period. We approached 144 women with breast cancer who were eligible for our study giving a participation rate for cases $100 \%$. Women were entered into the study if they had a confirmed pathological breast cancer diagnosed from the Pathology Department of the two main hospitals.

For each case, 1 age-matched (within 3 years) controls were recruited from women of the same area of residency, women without any history of breast problem, women participated in the screening for early detecting of breast cancer, and women who had a mammogram and free from breast cancer to ensure that they are pathologically free from breast cancer. The main reason for matching was to minimize confounding that may influence the outcome of investigated variables. Women with a history of neoplastic disease, pregnancy, hormonal, and gynecological condition were excluded from the study.

After taking informed consent from the women, a structured questionnaire was administered and completed at the time of recruitment including the following: demographic characteristics, physical environmental risk factors such as history of radiation exposure, chemical environmental risk factors such as history of ever-use contraceptive and hormonal therapy, lifestyle, diet, and pesticides exposure.

This study did not use "blinding" procedure with respect to the case status of subjects and it is possible that women who were diagnosed with breast cancer were more likely to provide more detailed complete information about past exposure history than controls. However, the researcher was fully familiarized about the possibility of recall/ interviewer bias and their potential impact on our study. A number of efforts were made to minimize such bias, including standardization of wording in the interview and repeat interviews for some participants.

The data were analyzed using SPSS version 15 [18]. Simple distribution and frequencies of the study variables, the cross tabulation, and normal Chi square had been applied. $P$ value had been calculated for the ordinal level measure $(P<0.05)$, variables that are statistically significant by Chi square test had been analyzed using Odds Ratio and 95\% Confidence Interval. 


\section{Results and Discussion}

\section{Breast cancer by sociodemographic variables}

Table I shows the sociodemographic characteristics of the subjects. There were a significant differences between cases and controls with regard to educational level and marital status $(P$ value $=0.001, P$ value $=0.003$ respectively $)$. Our findings suggest a relationship between marital status and breast cancer, which is consistent with findings in some studies [19.20], although it was not a significant risk factor for breast cancer in some other population [21]. The basis of this difference in different population is not clear and warrants further studies.

One hundred forty four women with breast cancer matched by age group and area of residency with 144 women pathologically free from breast cancer which were selected as controls. As controls were age-matched and area of residency-matched with cases, there was no significant difference between the two groups $(P$ value $=0.603, P$ value $=$ 0.713 respectively).

\section{Breast cancer by physical environmental factors}

Table 2 shows the physical environmental factors of the subjects. There were no significant differences between cases and controls with regard to X-ray exposure, and having a radiation therapy in the past as well. However, exposure to physical trauma on the breast was a significant risk factor $(\mathrm{OR}=12.80, P$ value $=0.001)$. Women exposed to physical trauma on breast were found to be at higher risk for breast cancer than women did not expose to such factor on the past which is consistent with findings in some studies [22,23].

\section{Breast cancer by oral contraceptive pills and medication for infertility treatment}

Table 3 shows the oral contraceptive pills and infertility medication of the subjects. There was no significant differences between cases and controls with regard to oral contraceptive. However, the study disclosed that the subjects treated with medication for infertility had a significantly higher risk of breast cancer compared to those without similar treatment, which was consistent with other studies [24,25]. Subject treated with such medication exhibit a six-fold excess risk (OR=6.22).

\section{Breast cancer by lifestyle}

Table 4 shows the lifestyle of the subjects. There was no significant differences between cases and controls with regard to using hair dyes, using anti-deodorants, using facial cosmetics and using hair removal ointments.

\section{Breast cancer by type of diet}

Table 4 shows the type of diets of the subjects. The study detected a significant differences between cases and controls with regard to type of diet, eating $500 \mathrm{gm} /$ week of red meat, eating chicken skin, eating raw vegetables weekly, buying fruits and vegetables at the beginning of the season, using some materials in cooking, and eating canned food. However, there were no significant differences between cases and controls with regard to washing vegetables.

As indicated in table 5, more than half of cases ate 500gm of red meat and more/ week which is inconsistent with the limited amount recommended by American Institution for Cancer Risk (2011) who recommended that to reduce cancer risk we should eat no more 510.3 gm of red meat/week. Red meat characterized by a rich source of fats where many chemicals could be accumulated there, this could be a warrants why eating more than 500gm red meat have a chance to get breast cancer, which is consistent with some findings in many studies [26,27]. 


\begin{tabular}{|c|c|c|c|c|c|c|}
\hline \multirow{2}{*}{\multicolumn{2}{|c|}{ Variable }} & \multicolumn{2}{|c|}{$\begin{array}{c}\text { Case } \\
(n=144)\end{array}$} & \multicolumn{2}{|c|}{$\begin{array}{l}\text { Control } \\
(n=144)\end{array}$} & \multirow{2}{*}{$\begin{array}{c}P . \\
\text { value }\end{array}$} \\
\hline & & No. & $\%$ & No. & $\%$ & \\
\hline \multirow{5}{*}{ Governorate } & North Gaza & 25 & 17.4 & 25 & 17.4 & \multirow{5}{*}{0.999} \\
\hline & Gaza & 37 & 25.7 & 35 & 24.3 & \\
\hline & Middle Zone & 16 & 11.1 & 17 & 11.8 & \\
\hline & Khan Yunis & 34 & 23.6 & 34 & 23.6 & \\
\hline & Rafah & 32 & 22.2 & 33 & 22.9 & \\
\hline \multirow{3}{*}{ Living area } & City & 53 & 36.8 & 52 & 36.1 & \multirow{3}{*}{0.713} \\
\hline & Camp & 51 & 35.4 & 57 & 39.6 & \\
\hline & Village & 40 & 27.8 & 35 & 24.3 & \\
\hline \multirow{5}{*}{ Age group } & $25-35$ & 16 & 11.1 & 15 & 10.4 & \multirow{5}{*}{0.603} \\
\hline & $36-46$ & 34 & 23.6 & 39 & 27.1 & \\
\hline & $47-57$ & 44 & 30.6 & 52 & 36.1 & \\
\hline & $58-68$ & 38 & 26.4 & 28 & 19.4 & \\
\hline & $69 \leq$ & 12 & 8.3 & 10 & 6.9 & \\
\hline \multirow{4}{*}{ Education } & $\begin{array}{l}\text { Less than } \\
\text { secondary }\end{array}$ & 79 & 54.9 & 46 & 31.9 & \multirow{4}{*}{0.001} \\
\hline & Secondary & 37 & 25.7 & 18 & 12.5 & \\
\hline & Diploma & 10 & 6.9 & 36 & 25.0 & \\
\hline & University & 18 & 12.5 & 44 & 30.6 & \\
\hline \multirow{4}{*}{ Marital status } & Married & 121 & 84.0 & 97 & 67.4 & \multirow{4}{*}{0.003} \\
\hline & Single & 7 & 4.9 & 14 & 9.7 & \\
\hline & Divorced & 3 & 2.1 & 15 & 10.4 & \\
\hline & Widowed & 13 & 9.0 & 18 & 12.5 & \\
\hline
\end{tabular}

Table 2: The physical environmental factors of the subjects.

\begin{tabular}{|c|c|c|c|c|c|c|c|c|}
\hline \multicolumn{2}{|l|}{ Variable } & \multicolumn{2}{|c|}{$\begin{array}{c}\text { Case } \\
(n=144)\end{array}$} & \multicolumn{2}{|c|}{$\begin{array}{l}\text { Control } \\
(n=144)\end{array}$} & \multirow{2}{*}{$\begin{array}{c}P \text {. } \\
\text { value }\end{array}$} & \multirow[t]{2}{*}{ Cl } & \multirow{2}{*}{$\begin{array}{l}\text { Odds } \\
\text { ratio }\end{array}$} \\
\hline & & No. & $\%$ & No. & $\%$ & & & \\
\hline \multirow{2}{*}{ Have $x$-ray in the past } & Yes & 64 & 44.4 & 62 & 43.1 & \multirow{2}{*}{0.812} & \multirow{2}{*}{$0.65-1.73$} & \multirow{2}{*}{1.06} \\
\hline & No & 80 & 55.6 & 82 & 56.9 & & & \\
\hline \multirow{2}{*}{$\begin{array}{l}\text { Radiation therapy in } \\
\text { the past }\end{array}$} & Yes & 2 & 1.4 & 2 & 1.4 & \multirow{2}{*}{1.00} & \multirow{2}{*}{$0.139-7.197$} & \multirow{2}{*}{1.00} \\
\hline & No & 142 & 98.6 & 142 & 98.6 & & & \\
\hline \multirow{2}{*}{$\begin{array}{l}\text { Exposed to trauma } \\
\text { on the breast }\end{array}$} & Yes & 22 & 15.3 & 2 & 1.4 & \multirow{2}{*}{0.001} & \multirow{2}{*}{$0.018-0.339$} & \multirow{2}{*}{12.80} \\
\hline & No & 122 & 84.7 & 142 & 98.6 & & & \\
\hline
\end{tabular}

Table 3: Oral contraceptive pills and medication for infertility of the subjects.

\begin{tabular}{|c|c|c|c|c|c|c|c|c|}
\hline \multirow{2}{*}{\multicolumn{2}{|c|}{ Variable }} & \multicolumn{2}{|c|}{$\begin{array}{c}\text { Case } \\
(n=144)\end{array}$} & \multicolumn{2}{|c|}{$\begin{array}{l}\text { Control } \\
(n=144)\end{array}$} & \multirow{2}{*}{$\begin{array}{c}P . \\
\text { Value }\end{array}$} & \multirow[t]{2}{*}{ Cl } & \multirow[t]{2}{*}{ Odds ratio } \\
\hline & & No. & $\%$ & No. & $\%$ & & & \\
\hline \multirow{2}{*}{ Contraceptive pills } & Yes & 34 & 23.6 & 37 & 25.7 & \multirow{2}{*}{0.682} & \multirow{2}{*}{$0.50-1.58$} & \multirow{2}{*}{0.89} \\
\hline & No & 110 & 76.4 & 107 & 74.3 & & & \\
\hline \multirow{2}{*}{$\begin{array}{l}\text { Infertility treatment } \\
\text { medication }\end{array}$} & Yes & 52 & 36.1 & 12 & 8.3 & \multirow{2}{*}{0.001} & \multirow{2}{*}{$3.01-13.0$} & \multirow{2}{*}{6.22} \\
\hline & No & 92 & 63.9 & 132 & 91.7 & & & \\
\hline
\end{tabular}

Table 4: The lifestyle of subjects.

\begin{tabular}{|c|c|c|c|c|c|c|c|c|}
\hline \multirow{2}{*}{\multicolumn{2}{|c|}{ Variable }} & \multicolumn{2}{|c|}{$\begin{array}{c}\text { Case } \\
(n=144)\end{array}$} & \multicolumn{2}{|c|}{ Control $(n=144)$} & \multirow{2}{*}{$\begin{array}{l}P . \\
\text { value }\end{array}$} & \multirow[t]{2}{*}{ Cl } & \multirow{2}{*}{$\begin{array}{l}\text { Odds } \\
\text { ratio }\end{array}$} \\
\hline & & No. & $\%$ & No. & $\%$ & & & \\
\hline \multirow{2}{*}{ Using hair dyes } & Yes & 72 & 50.0 & 71 & 49.3 & \multirow{2}{*}{0.906} & \multirow{2}{*}{$0.63-1.68$} & \multirow{2}{*}{1.03} \\
\hline & No & 72 & 50.0 & 73 & 50.7 & & & \\
\hline \multirow{2}{*}{ Using anti- deodorants } & Yes & 50 & 34.7 & 46 & 31.9 & \multirow{2}{*}{0.617} & \multirow{2}{*}{$0.67-1.91$} & \multirow{2}{*}{1.13} \\
\hline & No & 94 & 65.3 & 98 & 68.1 & & & \\
\hline \multirow{2}{*}{ Using facial cosmetics } & Yes & 101 & 70.1 & 106 & 73.6 & \multirow{2}{*}{0.512} & \multirow{2}{*}{$0.49-1.45$} & \multirow{2}{*}{0.842} \\
\hline & No & 43 & 29.9 & 38 & 26.4 & & & \\
\hline \multirow{2}{*}{$\begin{array}{l}\text { Using hair removal } \\
\text { ointments }\end{array}$} & Yes & 12 & 8.3 & 9 & 6.2 & \multirow[t]{2}{*}{0.497} & \multirow[t]{2}{*}{$0.51-3.65$} & \multirow[t]{2}{*}{1.36} \\
\hline & No & 132 & 91.7 & 135 & 93.8 & & & \\
\hline
\end{tabular}




\begin{tabular}{|c|c|c|c|c|c|c|c|c|}
\hline \multirow{2}{*}{\multicolumn{2}{|c|}{ Variable }} & \multicolumn{2}{|c|}{ Case } & \multicolumn{2}{|c|}{ Control } & \multirow{2}{*}{$\begin{array}{c}P \\
\text { Value }\end{array}$} & \multirow{2}{*}{$\mathrm{Cl}$} & \multirow{2}{*}{$\begin{array}{l}\text { Odds } \\
\text { ratio }\end{array}$} \\
\hline & & No. & $\%$ & No. & $\%$ & & & \\
\hline \multirow{3}{*}{ Type of diet } & Vegetarian & 1 & 0.7 & 5 & 4.2 & \multirow{4}{*}{0.001} & \multirow{4}{*}{ - } & \multirow{4}{*}{ - } \\
\hline & Animal & 15 & 10.4 & 0 & 0.0 & & & \\
\hline & Normal & 128 & 88.9 & 138 & 95.8 & & & \\
\hline \multicolumn{2}{|l|}{ Total } & 144 & 100 & 144 & 100 & & & \\
\hline \multirow{3}{*}{ Eating $500 \mathrm{gm} /$ week of red meat } & Yes & 59 & 41.0 & 23 & 16.0 & \multirow{4}{*}{0.001} & \multirow{4}{*}{-} & \multirow{4}{*}{ - } \\
\hline & $\begin{array}{c}\text { More than } \\
500 \mathrm{gm} / \text { week }\end{array}$ & 18 & 12.5 & 1 & 0.7 & & & \\
\hline & $\begin{array}{l}\text { Less than } \\
500 \mathrm{gm} / \text { week }\end{array}$ & 67 & 46.5 & 120 & 83.3 & & & \\
\hline \multicolumn{2}{|l|}{ Total } & 144 & 100 & 144 & 100 & & & \\
\hline \multirow{2}{*}{ Eating chicken skin } & Yes & 51 & 35.7 & 7 & 5.3 & \multirow{3}{*}{0.001} & \multirow{3}{*}{$\begin{array}{c}4.12 \\
-25.28\end{array}$} & \multirow{3}{*}{9.98} \\
\hline & No & 92 & 64.3 & 126 & 94.7 & & & \\
\hline \multicolumn{2}{|l|}{ Total } & 143 & 100 & 133 & 100 & & & \\
\hline \multirow{3}{*}{$\begin{array}{c}\text { Eating raw } \\
\text { vegetables weekly }\end{array}$} & Large amount & 4 & 2.8 & 36 & 25.0 & \multirow{3}{*}{0.001} & \multirow{3}{*}{-} & \multirow{3}{*}{-} \\
\hline & $\begin{array}{c}\text { Moderate } \\
\text { amount }\end{array}$ & 110 & 76.4 & 108 & 75.0 & & & \\
\hline & Small amount & 30 & 20.8 & 0 & 0.0 & & & \\
\hline \multirow{3}{*}{$\begin{array}{c}\text { Eating } \\
\text { cooked vegetables weekly }\end{array}$} & Large amount & 3 & 2.1 & 25 & 17.4 & \multirow{3}{*}{0.001} & \multirow{3}{*}{ - } & \multirow{3}{*}{-} \\
\hline & $\begin{array}{c}\text { Moderate } \\
\text { amount }\end{array}$ & 111 & 77.1 & 119 & 82.6 & & & \\
\hline & Small amount & 30 & 20.8 & 0 & 0.0 & & & \\
\hline Buying fruits and vegetables at the & Yes & 119 & 82.6 & 12 & 8.3 & \multirow{2}{*}{0.001} & 23.91- & 5236 \\
\hline beginning of the season & No & 25 & 17.4 & 132 & 91.7 & & 117.24 & 52.00 \\
\hline Waching veretablec and fruitc & Yes & 142 & 98.6 & 143 & 99.3 & 0562 & $002-706$ & 0.50 \\
\hline vasining vegetanies andu muts & No & 2 & 1.4 & 1 & 0.7 & 0.502 & $0.02-1.00$ & 0.00 \\
\hline & Olive oil & 9 & 6.3 & 3 & 2.1 & & & \\
\hline Materials used in conking & Butter & 2 & 1.4 & 2 & 1.4 & $0 \cap 01$ & - & - \\
\hline iviaterials usen in Couking & Margarine & 16 & 11.1 & 1 & 0.7 & 0.001 & - & - \\
\hline & Others & 117 & 81.3 & 3138 & 95.8 & & & \\
\hline Eating & Yes & 107 & 74.3 & 92 & 63.9 & 0.05 & $096-280$ & 163 \\
\hline Canned food & No & 37 & 25.7 & 52 & 36.1 & 0.00 & $0.90-2.00$ & 1.00 \\
\hline
\end{tabular}

Others reported that the temperature used for meat cooking plays a significant role in affecting breast cancer risk where amino acids could react with a creatine at high temperature to produce heterocyclic amine which is known as a carcinogenic compound [28]. The methods of preparing meat is playing a significant role in human cancers where polycyclic aromatic hydrocarbons adhere to the surface of meat, and the more intensive the heat, the more polycyclic aromatic hydrocarbons are present [29].

Chicken typically are raised in factory farms under extremely confined and unsanitary conditions that require use of antibiotics and antimicrobial drugs to maintain their health and maximize their growth. Palestinian society depends in their diets on chicken as a source of protein and other vitamins such as B 12, but the majority of the population like a small weight chicken more than the big one which exposed them to more accumulated chemicals in chicken especially in fats under the skin like dioxins [30]. Also the preparation methods of chicken plays an important role in the production of a well-known carcinogenic compound (Heterocyclic Amines) which is produced by the reaction between amino acids and creatine under high temperature [28]. Polycyclic aromatic hydrocarbons also can adhere to the skin of chicken during grilling of chicken, and the more intense the heat, the more polycyclic aromatic hydrocarbons are presents which play a significant role in human cancer [29].

Regarding eating raw vegetables, our findings were inconsistent with other findings in many studies. So that, the researcher suggest that the excess use of pesticides in Gaza Strip which might be deposit in vegetables where there was no protocols to monitor pesticides residues in agricultural crops that might endanger the health of the whole population in Gaza Strip [6,31]. In this regard, we can say that vegetables used in Gaza Strip may have been exposed to many pesticides that do not have control during use in 
addition to the exposure of these chemicals to high temperature which may lead them to produce more dangerous chemicals on human health especially during cooking.

Regarding buying fruits and vegetables at the beginning of the season, this factor seriously affect the chance of getting breast cancer where women who bought vegetables and fruits at the beginning of their season had a chance of getting breast cancer fifty two times $(\mathrm{OR}=52.36)$ more than women who did not buy them at the beginning of the season. Therefore, it is considered as a risk factor of breast cancer among women. As we know, vegetables and fruits in Gaza Strip exposed to high amounts of pesticides that accumulate in them especially at the beginning of their season, also some farmers exploit the beginning of vegetables and fruits season to sell them in markets in order to get the highest price, irrespective of the extent of danger on human health.

Thiebaut et al. [32], showed that there were association between saturated and monounsaturated fat intake with the risk of postmenopausal invasive breast cancer. Sierris et al. [27] and Balasubramaniam et al. [33] showed that there were an association between high saturated fat intake and breast cancer risk and there were no significant association of breast cancer with total monounsaturated or polyunsaturated fats. As well known, butter is loaded with saturated fats and is ultimate high fat dairy product which may also contain residues of pesticides mainly chlorinated hydrocarbons and other environmental toxins that tend to concentrate in fats, making high-fat dairy products more dangerous than low fats or, especially, nonfat ones.

Regarding canned food, they are imported to us from unknown source so they might contain some toxic chemicals such as pesticides that might effect on women health. Bisphenol A is an unstable polymer that presented as a liner in canned food is a lipophilic, it can leach into food products especially when heated [34]. The researcher think that we need precise information about the dose of BPA taken by women during their depending on canned food if we need to be accurate in judgment on BPA effects on breast cancer risk.

\section{Breast cancer by pesticides}

Table 6 shows exposure of subjects to pesticides. There was a significant differences between cases and controls with regard to all variables mentioned in table VI except the variable buying and transporting of pesticides.

As well known, living in a farm or beside a farm and a rural area makes women more vulnerable to environmental hazards of which they are exposed through the food they eat, the air they breathe, and the water they drink. Actually, all factors included in pesticides domain showed a direct contact with these pesticides through the three routs of exposure absorption, digestion and inhalation. During pesticides domain, mainly all the variables related to it are associated with the risk of breast cancer. Pesticides still one the most serious public health problems in Gaza Strip by which there were uncontrolled and heavy use of pesticides and some of these pesticides are internationally suspended, banned, and cancelled are still used in the agricultural environment of Gaza Strip [15-17].

It is very important to mention here that there were more than 900 metric tons of formulated pesticides used annually in Gaza Strip, with more than 10,000 tons of organic fertilizers also were used annually in 2001 in the presence of formal Ministry of Agriculture [6]. Nowadays could we imagine the amount of pesticides currently used in Gaza Strip where tunnels open for everyone to import anything without monitoring and clear rules and regulations regarding to the kinds of pesticides that are safety for users and general population.

There were no protocols to monitor pesticides residues in agricultural crops that might endanger the health of whole population in Gaza [6,31], also there were 


\begin{tabular}{|c|c|c|c|c|c|c|c|c|}
\hline \multirow{2}{*}{\multicolumn{2}{|c|}{ Variable }} & \multicolumn{2}{|c|}{ Case } & \multicolumn{2}{|c|}{ Control } & \multirow{2}{*}{$\begin{array}{c}\text { P. } \\
\text { Value }\end{array}$} & \multirow{2}{*}{ CI } & \multirow{2}{*}{$\begin{array}{l}\text { Odds } \\
\text { ratio }\end{array}$} \\
\hline & & No. & $\%$ & No. & $\%$ & & & \\
\hline \multirow{2}{*}{ Living in a farm } & Yes & 71 & 49.3 & 55 & 38.2 & \multirow{3}{*}{0.05} & \multirow{3}{*}{$0.96-2.59$} & \multirow{3}{*}{1.57} \\
\hline & No & 73 & 50.7 & 89 & 61.8 & & & \\
\hline \multicolumn{2}{|l|}{ Total } & 144 & 100 & 144 & 100 & & & \\
\hline \multirow{3}{*}{ Period of living in a farm } & $\leq 20 \mathrm{Y}$ & 59 & 83.1 & 40 & 72.7 & \multirow{4}{*}{0.05} & \multirow{4}{*}{ - } & \multirow{4}{*}{ - } \\
\hline & $21-40$ & 12 & 16.9 & 11 & 20.0 & & & \\
\hline & $\geq 41 \mathrm{Y}$ & 0 & 0 & 4 & 7.3 & & & \\
\hline \multicolumn{2}{|l|}{ Total } & 71 & 100 & 55 & 100 & & & \\
\hline \multirow{2}{*}{ Pesticides used in the farm } & Yes & 65 & 91.5 & 36 & 65.5 & \multirow{3}{*}{0.001} & \multirow{3}{*}{$1.92-17.75$} & \multirow{3}{*}{5.72} \\
\hline & No & 6 & 8.5 & 19 & 34.5 & & & \\
\hline \multicolumn{2}{|l|}{ Total } & 71 & 100 & 55 & 100 & & & \\
\hline Working with cronc he noked hands & Yes & 29 & 20.1 & 5 & 3.5 & & & \\
\hline Working witn crops by naked nands & No & 115 & 79.9 & 139 & 96.5 & 0.001 & $2.48-21.36$ & 7.01 \\
\hline Total & & 144 & 100 & 144 & 100 & & & \\
\hline Working in the field while pesticides applied & Yes & 30 & 20.8 & 1 & 0.7 & & & \\
\hline at the same time or within 24 hours & No & 114 & 79.2 & 143 & 99.3 & 0.001 & $5.37-753.1$ & 37.63 \\
\hline Total & & 144 & 100 & 144 & 100 & & & \\
\hline Buving and transnorting of necticides & Yes & 2 & 1.4 & 0 & 0.0 & & & \\
\hline Duymy antu tiansporting o i pestictues & No & 142 & 98.6 & 144 & 100 & 0.156 & - & - \\
\hline Total & & 144 & 100 & 144 & 100 & & & \\
\hline Cleaning of pesticides mixing and & Yes & 22 & 15.3 & 2 & 1.4 & & & \\
\hline application equipments & No & 122 & 84.7 & 142 & 98.6 & 0.001 & $2.83-80.46$ & 12.80 \\
\hline Total & & 71 & 100 & 55 & 100 & & & \\
\hline Percenal anplication of necticidec & Yes & 7 & 4.9 & 0 & 0.0 & & & \\
\hline Pelsomial appication or pesticiaes & No & 137 & 95.1 & 144 & 100 & 0.007 & - & - \\
\hline Total & & 144 & 100 & 144 & 100 & & & \\
\hline Living with anvone worked in a farm & Yes & 30 & 20.8 & 17 & 11.8 & & & \\
\hline & No & 114 & 79.2 & 127 & 88.2 & 0.038 & $0.99-3.95$ & 1.97 \\
\hline Total & & 144 & 100 & 144 & 100 & & & \\
\hline Contact with working cloths, tools, & Yes & 27 & 90.0 & 5 & 29.4 & & & \\
\hline equipment & No & 3 & 10.0 & 12 & 70.6 & 0.001 & $\begin{array}{c}3.65- \\
152.60\end{array}$ & 21.6 \\
\hline Total & & 30 & 100 & 17 & 100 & & & \\
\hline Father, mother & Yes & 34 & 23.6 & 19 & 13.2 & & & \\
\hline brother, sister working in a farm & No & 110 & 76.4 & 125 & 86.8 & 0.023 & $1.05-3.95$ & 2.03 \\
\hline Total & & 144 & 100 & 144 & 100 & & & \\
\hline & $\leq 10 Y$ & 14 & 41.2 & 7 & 36.8 & & & \\
\hline Perind of living with them & $11-21$ & 15 & 44.1 & 4 & 21.1 & & & \\
\hline 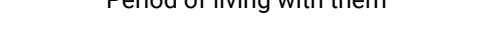 & $22-32$ & 1 & 2.9 & 6 & 31.6 & 0.024 & - & - \\
\hline & $\geq 33$ & 4 & 11.8 & 2 & 10.5 & & & \\
\hline Total & & 34 & 100 & 19 & 100 & & & \\
\hline Living hecide a farm or rural area & Yes & 67 & 46.5 & 46 & 31.9 & & & \\
\hline Living Deside a rarm or rural area & No & 77 & 53.5 & 98 & 68.1 & 0.011 & $1.12-3.08$ & 1.85 \\
\hline Total & & 144 & 100 & 144 & 100 & & & \\
\hline Smelling strange odors like pesticides. & Yes & 66 & 98.5 & 21 & 45.7 & & & \\
\hline & No & 1 & 1.5 & 25 & 54.3 & 0.001 & $\begin{array}{l}10.19- \\
1651.7\end{array}$ & 78.57 \\
\hline Total & & 67 & 100 & 46 & 100 & & & \\
\hline
\end{tabular}

no restrictions on the sale and use of pesticides in Gaza, farmers have easy access to all pesticides including banned, highly toxic and restricted species. Therefore, all of the above makes users of pesticides and general population in particular women vulnerable to public health problems such as breast cancer.

Our findings showed that women who worked in the field at the time of applying pesticides or during 24 hours of their application had elevation in breast cancer risk which supported by Duell et al. [35] and Ferro et al. [36] who reported that there were an increased risk of breast cancer in women who likely exposed to pesticides in particular women present in field during or shortly after pesticides application. Also Brophy et al. [37], support our results through his findings that find a 3-9 fold increase in incidence of breast cancer amongst women with history of agriculture. Findings also showed that living beside a rural area or in a farm lead to increase the risk of 
breast cancer which is also supported by Engle et al. [38] who found an elevated risk of breast cancer among women who's their homes were closest to area of pesticides application. Band et al. [39], found a significant association in both menopausal and postmenopausal women between breast cancer and involvement in crop farming and fruits and vegetables production which was likely exposed to pesticides which support our study findings.

\section{References}

1. Ferlay J, Shin HR, Bray F, Forman D, Mathers CD, Parkin D. GLOBOCAN 2008, Cancer incidence and mortality Worldwide: IARC Cancer base No. 10. International Agency for Research on Cancer. Ref.: https://goo.gl/yXoN1k

2. Sarhan. Breast cancer in Eastern Mediterranean Region. Paper presented at the international symposium on breast cancer in developing world: meeting the unforeseen challenge to women, health, and equity. 2009;

3. Salim JM, Moore MA, Al-lawati JA, Al-sayad J, Bawazir A, et al. Cancer epidemiology and control in Arab World-past, present and future. Asian Pac J Cancer Prev. 10: 3-16. Ref.: https://goo.gl/6EcCof

4. Ministry of Health. The status of health in Palestine. Annual report. Palestine.

5. Richter ED, Safi J. Pesticide use, exposure, and risk. A joint Israeli-Palestinian perspective. Environ Res. 37: 211-218. Ref.: https://goo.gl/en8VTt

6. Safi JM. Association between chronic exposure to pesticides and recorded cases of human malignancy in Gaza Governorates (1990-1999). Sci Total Environ 284: 75-84. Ref.: https://goo.gl/6ZqWuV

7. Cancer Registry Center, 2010. Cancer Status in Palestine, Gaza Strip, Palestine

8. Key TJ, Verkasalo PK, Banks E. Epidemiology of breast cancer. The Lancet Oncology. 2001; 2: 133140. Ref.: https://goo.gl/NpYMbD

9. Lafta R, Saeed E, Isa S. Risk factors of breast cancer among women (A sample from Baghdad). Iraqi J Comm Med. 2013; 1: 1-6. Ref.: https://goo.gl/rvwmkQ

10. Cauchi JP, Camilleri L, Scerri C. Environmental and lifestyle risk factors of breast cancer in Malta-a retrospective case-control study. EPMA J. 2016; 7: 20. Ref.: https://goo.gl/V7jqFo

11. Gray J. State of the evidence; the connection between breast cancer and the environment. $5^{\text {th }}$ edition, Breast Cancer Fund. 2010; 14.

12. Charlier CJ, Dejardin MTC. Increased risk of relapse after breast cancer with exposure to organochlorine pollutants. Bull Environ Contam Toxicol. 2007; 78: 1-4. Ref.: https://goo.gl/n745Yk

13. Watts M. Pesticides and Breast Cancer: A wake up call. PNA, Asia and the Pacific: Malaysia 2007; 61-101. Ref.: https://goo.gl/B51nsz

14. Rodgers KM, Udesky JO, Rudel RA, Brody JG. Environmental chemicals and breast cancer: An updated review of epidemiological literature informed by biological mechanisms. Environ Res. 2018; 160: 152-182. Ref.: https://goo.gl/79Fks3

15. Safi JM. The state of the environment in Gaza Strip. Alex Sci. 1998; 19: 137-150. Ref.: https://goo.gl/d6eRh2

16. Safi JM, El-Nahhal YZ, Soliman SA, El-Sebae AH. Mutagenic and carcinogenic pesticides used in Gaza Strip agricultural environment. The Science of the Total Environment. 1993; 123:371-380. Ref.: https://goo.gl/7GtZZm

17. Shomar BH, Muller G, Yahya A. Occurrence of pesticides in ground water and topsoil of The Gaza Strip. Water, Air, and Soil Pollution Journal. 2006; 171: 237-251. Ref.: https://goo.gl/W6Fhkn

18. Statistical Package for Social Science, 2007. Inc. Chicago, USA.

19. Pakseresh S, Ingle GA, Bahadur AK, Rameteke VK, Sighn MM, et al. Risk factors with breast cancer among women in Delhi. Indian J Cancer. 2009; 46: 132-138. Ref.: https://goo.gl/q2wHeu

20. Hinyard L, Wirth LS, Clancy JM, Schwartz T. The effect of marital status on breast cancer-related outcomes in women under 65: A SEER database analysis. Breast. 2017; 32: 13-17. Ref.: https://goo.gl/qiM6XW

21. Darweesh A. Risk factors of breast cancer among Palestinian women in North West Bank. MSc Thesis, An-Najah National University, Nablus, Palestine. 2009; Ref.: https://goo.gl/CjsEzF 
22. Rigby JE, Morris JA, Lavelle J, Stewart M, Gatell AC. Can physical trauma cause breast cancer? European J of Cancer Prevention. 2002; 11: 307-311. Ref.: https://goo.gl/qeKW1S

23. Memon Z, Ain Q, Khan R, Raza N, Noor T. Clinical presentation and frequency of risk factors in patients with breast carcinoma in Pakistan. Asian Pac J Cancer Prev. 2015; 16: 7467-7472. Ref.: https://goo.gl/jp4X4j

24. Brinton LA, Scoccia B, Moghissi KS, Westhoff CL, Althuis MD, et al. Breast cancer risk associated with ovulation-stimulating drugs. Hum Reprod. 2005; 19: 2005-2013. Ref.: https://goo.gl/wyvm3j

25. Reigstad MM, Storeng R, Myklebust TÅ, Oldereid NB, Omland AK, et al. Cancer risk in women treated with fertility drugs according to parity status- A registry-based cohort study. Cancer Epidemiol Biomarkers Prev. 2007; 26: 953-962. Ref.: https://goo.gl/AWJr99

26. Linos E, Willett WC, Cho E, Golditz, Frazier LA. Red meat consumption during adolescence among premenopausal women and risk of breast cancer. Cancer Epidemiol Biomarkers Prev. 2008; 17: 2146-2151. Ref.: https://goo.gl/cqYxTt

27. Sierris S, Krogh V, Ferrari $P$, Berrino F, Pala V, et al. Dietary fat and breast cancer risk in the European Prospective Investigation into Cancer and Nutrition. Am J Clan Nut. 2008; 88: 1304-1312. Ref.: https://goo.gl/mxaJ5R

28. National Cancer Institute. Chemicals in meat cooked at high temperature and cancer risk. 2011; Ref.: https://goo.gl/pifPMb

29. Norat T, Riboli E. Meat consumption and colorectal cancer: a review of epidemiologic evidence. Nut Rev. 2001; 59: 37-47. Ref.: https://goo.gl/mC7aDY

30. WHO. Dioxins and their effects on human health. Fact sheet 225. 2007;

31. Safi JM, Abou-Foul NS, El-Nahal Y, El-Sebae AH. Monitoring of pesticide residues on green pepper, potatoes, vice faba, green bean and green peas in Gaza Governorates, Palestine. J Pest cont Environ Sci. 2001; 9: 55-72 Ref.: https://goo.gl/9GHgjL

32. Thiebaut AC, Kipnis V, Chang SC, Subar AF, Thompson FE, et al. Dietary fat and postmenopausal invasive breast cancer in the National Institute of Health- AARP Diet and Health Study Cohort. J Nati Cancer Inst. 2007; 99: 451-462. Ref.: https://goo.gl/KgJZ1V

33. Balasubramaniam SM, Rotti SB, Vivekanandam S. Risk factors of female breast carcinoma: a case control study at Puducherry. Indian J Cancer. 2013; 50: 65-70. Ref.: https://goo.gl/9kmRJU

34. Brotons JA, Olea-Serrano MF, Villalobos M, Pedraza V, Olea N. Xenoestrogen released from lacquer coating in food cans. Environ Health Perspect. 1995; 103: 608-612. Ref.: https://goo.gl/AujTwf

35. Duell EJ, Millikan RC, Savitz DA, Newman B, Smith JC, et al. A population- based case- control study of farming and breast cancer in North Carolina. Epidemiol. 2000; 11: 523-531. Ref.: https://goo.gl/Hx6NJk

36. Ferro R, Parvathaneni A, Patel S, Cheriyath P. Pesticides and Breast Cancer. Advances in Breast Cancer Research. 2012; 1: 30-35. Ref.: https://goo.gl/gSbSNh

37. Brophy JT, Keith MM, Gorcy KM, Laukkanen E, Hellyer D, et al. Occupational histories of cancer patients in a Canadian cancer treatment center and general hypothesis regarding breast cancer and farming. Int J Occup Environ Health0 2002; 8: 346-353. Ref.: https://goo.gl/Z3GmmT

38. Engel LS, Hill DA, Hoppin JA, Lubin JH, Alavanja MC. Pesticides and breast cancer risk among farmers' wives in the agricultural health study. Am J Epidemiol. 2005; 161: 121-135. Ref.: https://goo.gl/HK5ydm

39. Band PR, Le ND, Fang R, Deschamps M, Gallagher RP, et al. Identification of occupational cancer risk in British Columbia: a population-based case-control study of 995 incident breast cancer cases by menopausal status, controlling for confounding factors. J Occup Environ Med. 2002; 42: 284-310. Ref.: https://goo.gl/4itZ3E 